
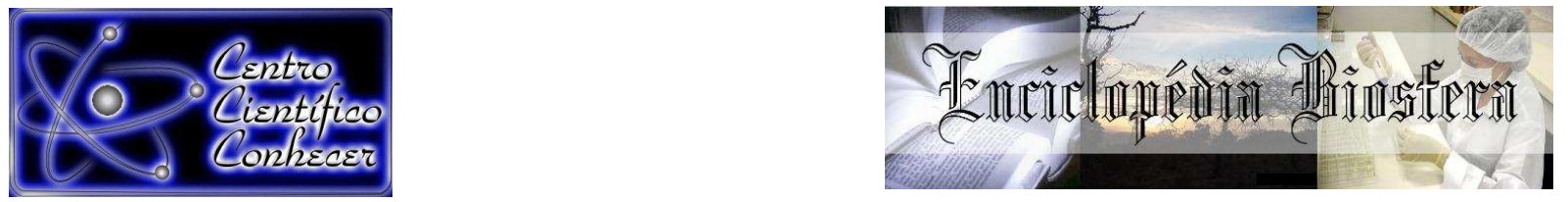

\title{
O OLHAR POETICO DE LEODEGÁRIA NA POESIA GOIANA
}

\section{Cosme Juares Moreira Streglio'; Maria de Fátima Gonçalves Lima²}

1 Mestre em Letras/Área de concentração: Critica Literária. Pontifícia Universidade Católica de Goiás Puc Goiás. Ano da Obtenção do titulo: 2015. Atualmente é professor do Colégio Estadual Santa Luzia em Aparecida de Goiânia.

2 Pos- doutora pela Pontifícia Universidade Católica do Rio de Janeiro.(Puc/ Rio. 2009). Docente do Curso de Letras Puc/ Goiás. Tem experiência na área de letras e linguagem jurídica, atuando nos principais temas: Literatura Brasileira, Critica Literária e teoria do texto poético. É ensaísta e autora de obras de critica literária e infanto juvenil.

Recebido em: 08/04/2016 - Aprovado em: 30/05/2016 - Publicado em: 20/06/2016

DOI: 10.18677/Enciclopedia_Biosfera_2016_136

\section{RESUMO}

Leodegaria de Jesus, a poetisa goiana, trouxe para a lírica feminina o olhar da sensibilidade e do romantismo criando dessa forma, o eu lírico presente na obra Coroa de Lírios. O estudo sobre a poetisa de modo particular: ao poemas presentes em Coroa de Lírios, é ao mesmo tempo perceber a dinâmica da vivacidade da criação de um mundo poético idealizado e da presença de antítese marcado pelo romantismo: do pessimismo, morte, paixão e dor. Tal dinâmica presente na lírica de Coroa de Lírios apresenta a estrutura rítmica deixada por Luiz Camões como: Soneto composto por quarteto e terceto e rimas entre os versos terminados em vogais como se verifica em poemas como: Triste Viver. Dessa forma, ler e estudar a lírica feminina especificamente em Leodegaria, é descobrir que esta poética possui características como: harmonia e vivacidade e antítese que se concentram nos principais poemas: Símile, Supremo Gozo e Triste Viver.

Palavras chave: Poesia Goiana. Leodegária. Devaneio.

\section{Aspectos históricos da poesia Goiana}

A literatura goiana ${ }^{1}$ tem inicio por volta do século $\mathrm{XVII}$ e tem influencias com literatura arcadista e barroca. Todavia, interessa para o presente estudo a poesia do inicio do século $X X$, época em que viveu Leodegaria, que é tema central do presente artigo.

$1 \square$ A poesia Goiana está dividida em seis períodos, a poética de Leodegaria esteve na terceira geração que vai de 1903 a 1930 (TELES, MENDONÇA. Poesia em Goiás, 1982) 
Assim, de acordo com TELES (1982) De 1903 a 1930 ocorreu no Estado de Goiás pelo menos nos primeiros séculos, a publicação de obras poéticas, houveram também possíveis desafios como a falta de recursos financeiros encontrados por alguns poetas e a dificuldade que tiveram para serem reconhecidos na Literatura. Goiana. De acordo com DENOFRIO (2001) Houve a formação dos primeiros círculos literários que apareceram em Goiás por volta de 1904 em que nesse ambiente cultural aparece Leodegária, uma jovem poetisa que desde muito cedo já revelou o dom estimado pela escrita e com o tempo vai se aperfeiçoando em meios as críticas que recebia por parte de poetas como: Gastão de Deus e Augusto Rios. Tais criticas eram referente a sua imaturidade e o pouco conhecimento teórico por parte da jovem poetisa, mas que ao mesmo tempo Leodegaria poderia apresentar grandes expectativas para a poetisa goiana sendo dessa forma a primeira mulher a ter um livro de poesia publicado.

A partir de 1901, existiram grandes produções literárias em Goiás no qual o professor Gilberto Mendonça Teles Cita as principais. No qual será demonstrada na seguinte ordem:

Quadro I: Produções poéticas de 1901 a 1913.

$\begin{array}{lll}\text { Nome do Livro } & \text { Nome do Autor } & \text { Ano da publicação } \\ \text { Poetas Goianos } & \text { Henrique Silva } & 1901 \\ \text { Alvorada } & \text { Joaquim Bonifácio } & 1902 \\ \text { Violetas } & \text { Luiz do Couto } & 1904 \\ \text { Agapanthos } & \text { Gastão de Deus } & 1906 \\ \text { Poesias } & \text { Felix de Bulhões } & 1906 \\ \text { Coroa de Lírios } & \text { Leodegaria de Jesus } & 1906 \\ \text { lluminare } & \text { Erico Durado } & 1911 \\ \text { Alguns Versos } & \text { Joaquim Bonifácio } & 1913\end{array}$

Segundo TELES (1982) a produção literária goiana em meados do inicio do século XX foi marcada por um romantismo tanto da primeira fase tendo como influência: Gonçalves Dias e Castro Alves, bem como uma poesia marcada pelo pessimismo e angustia que tem origens na poesia denominada: mal do século e tem como poeta principal: Álvares de Azevedo. Houve também a influência do parnasianismo, tema poético que busca a harmonia entre a palavras, ou seja, a coerência entre os versos. Dessa forma, os parnasianos eram rigorosos quanto a elaboração dos versos poéticos, tais poetas que se inspiraram nos parnasianos foram: Gastão de Deus ${ }^{2}$ e Joaquim Bonifácio. A poetisa Leodegaria de Jesus, tema central do presente estudo buscou se inspirar numa poesia romântica tanto da primeira fase que tem como foco a idealização amorosa e por outro lado no romantismo de segunda fase tendo como características marcantes: o pessimismo e a desilusão amorosa e a fuga constante do real. Dessa

2

Poeta que mesmo apresentando severas criticas a poetisa Leodegaria, auxiliou-a quando na organização da obra: Coroa de Lírios. (FRANÇA, Basileu. Leodegaria. Editora Kelps,1996) 
forma como explica DENOFRIO (2001) é marcante no eu-lírico de Leodegaria a ideia de uma poesia com antíteses aonde é presente a ideia de um amor idealizado e ao mesmo tempo um amor marcado por dor e sofrimento.

Segundo TELES (1982) a literatura em Goiás no inicio do século XX, foi marcada por inovações, entre elas estão as publicações de obras poéticas surgindo um novo caminho para a literatura. Todavia, a produção poética é tipicamente masculina, não houve poesia no campo eu-lírico feminino. As primeiras tentativas quanto a poesia na esfera feminina foi Cora Coralina e Leodegaria. Cora Coralina ainda não escrevia poesia e sim contos, sua primeira escrita foi o conto: Tragédia na Roça, publicado para um jornal da época chamado Goiazes. Todavia, Cora-Coralina quando escreveu "Tragédia na Rosa" por volta de 1910 ainda não tinha um livro publicado sendo reconhecida artisticamente bem mais tarde desse modo, a presente poetisa só foi reconhecida como uma artista da palavra somente em 1956 com a publicação do livro titulado: Estórias do Becos de Goiás ${ }^{3}$.

DENOFRIO (2001) demonstra que Cora oferta à amiga Leodegária o primeiro exemplar do livro que conta em forma de versos poéticos toda a trajetória da cidade de Goiás bem como as vivencias de Cora Coralina nas terras Goianas. Outra que se fez importante para a literatura da época foi Leodegaria. Todavia, tal poesia é pouco estudada no mundo acadêmico. Com isso, é de suma importância resgatar o que esta poetisa trouxe para a cultura goiana tal como poemas que viraram serenatas cantadas nas noites de finais de semanas na década de 30 e 40 no centro de Goiânia tal como o poema símile que está no livro: Coroa de Lírios. FRANÇA (1996) Tratando da poetisa Leodegaria de Jesus, a jovem escreve seus primeiros versos poéticos com o auxilio do pai e se encoraja com o apoio da família na produção de um livro intitulado: Cora de Lírios que foi reproduzido em Campinas SP pela editora Azul por volta de 1906. Portanto, Leodegaria foi a primeira mulher a ter um livro de poesia publicado contudo, a editoração se realizou no estado de São Paulo.

\section{Dados Biográficos}

De acordo com FRANÇA (1996), Leodegaria de Jesus nasceu em Caldas Novas no dia 8 de Agosto de 1889 e faleceu em Belo Horizonte no dia 12 de Julho de 1978 na casa onde morava. Segundo Basileu Toleto França, a poetisa tinha duas irmãs: Zenóbia e Maria Aurora. DENOFRIO (2001) explica que em 1903, Leodogaria Brazilia de Jesus pretendia-se a submeter aos exames para ingressar no Liceu de Goiás, mas foi negada. Havia nesta questão, impasses políticos com o seu pai.

FRANÇA (1996) traz informação de que a poetisa começou a ler na escolinha de Jataí, descobrindo as primeiras letras por meio da Sagrada Escritura. Outro aspecto

3

Este livro fez com Cora Coralina fosse reconhecida como poetisa no estado de Goiás. Cora oferta a primeira versão do livro a estimada amiga Leodegaria.(DENOFRIO, Darcy França, Lavras de Goiás, 2001) 
muito importante que traz Basileu Toleto França é que a poetisa teve uma educação exemplar em casa pelos seus pais. A casa da poetisa era um lugar de aprendizagem.

O sonho de Leodegária de Jesus de estudar no Liceu de Goiânia era muito grande, todavia foi algo muito difícil e um dos motivos foram conflitos políticos que seu pai enfrentou. Darcy França argumenta porque depois de ser examinado por uma banca do Rio de Janeiro, o resultado apareceu só seis anos depois. O resultado só veio como explica DENOFRIO (2001) quando a poetisa Leodegária de Jesus resolve se mudar para Catalão, neste lapso de tempo acabou por fazer o curso normal tornando se professora, seguindo a carreira do seu pai José Antonio de Jesus.

Neste Contexto, argumenta Darcy França Denófrio:

O período de Seis anos que levaram para conferir-Ihe o resultado do referido exame teria dado há ela tempo suficiente para cursar o Normal por duas ou mais vezes consecutivas. Com os "preparatórios", de 1904 sonharia certamente Leodegária com a Academia de Direitos, curso jurídico recém-criado na cidade de Goiás. Os chamados "exames gerais preparatórios eram pré-condição para o seu futuro ingresso no curso. (DENOFRIO,2001, p. 12 -13)

DENOFRIO (2001) e FRANÇA (1996) relatam que apesar das dificuldades que Leodegária enfrentou na sua época, a poetisa tinha um interesse enorme pelos estudos. Recebeu após o termino do curso normal, aulas particulares de: Português, Matemática, Literatura, o pai da poetisa ficou encarregado de lhe ensinar o Latim, língua que usou em alguns dos seus poemas.

\section{Aspectos básicos da poesia de Leodegária}

Todos os poemas de Leodegaria de Jesus estão reunidos em dois livros: 0 primeiro se chama: Coroa de Lírios e o Outro é o Livro Orquideas.

Para relatar sobre a poetisa Leodegaria de Jesus, será necessário compreender que a sua poética estar voltado para o tema amor tanto na esfera de idealização como também numa esfera de sofrimento. Dessa forma, em Coroa de Lírios, o tema amor é abordado por Leodegaria traz uma dinâmica entre o ser ideológico/amor perfeito e o ser real/ sofrimento essa antítese entre o ideal e o real é uma idealização platônica como relata FRIEDRICH (1978). O poeta não está voltado para o real e sim para o irreal e a função do poeta é imaginar e criar tendo o foco ideal de um amor sublime e puro. Tal conceito é possível ser visto no verso abaixo:

Quando em teus lábios frescos e mimosos

Paira um sorriso, cheio de brandura. Então, minha alma

As regiões dos gozos sente-se evoluir-se plena de ventura

(JESUS, 1906, p.49) 
Na obra Cora de Lírios, o eu-lírico ao construir a ideia de um amor perfeito está ao mesmo tempo tentando fugir da angustia existencial e ao mesmo tempo estabelecendo um caminho de acontecimentos possíveis dentro do mundo poético pois o poeta relata as coisas que são possíveis de acontecer (ARISTOTELES, 2005, p. 28)

Para perceber a importância da poesia em Goiás, um dos estudiosos da estrutura poética: PAZ(1982), argumenta a poesia é conhecimento, salvação, saber, abandono. Operação capaz de transformar o mundo. A atitude poética é revolucionária por natureza, é exercício espiritual, é um método de libertação interior. A poesia revela esse mundo; cria outro.

Roberto de Oliveira Brandão no prefácio do livro A poética clássica, citando Horacio, afirma que o bom poeta deverá ter domínio das palavras, sendo possível somente através do uso da razão e da técnica da arte. (ARISTOTELES, 2005, p.8)

O Livro Coroa de Lírios é o primeiro a ser publicado em Goiás em 1906 por uma mulher, ele está organizado da seguinte forma: Um prefácio feito por Felício Buarte, Aos Patrícios (termo utilizado pela poetisa para falar do motivo da escrita do seu livro) Paisagem, Mater, Símile, Ninho vazio, Maio, Osculo materno, Chromo, Jatahy, Setembro, Triste Viver, Estâncias. A primeira publicação do livro foi feita em Campinas (SP).(DENOFRIO , 2001)

Basíleu França relata que Leodegária de Jesus foi muito influenciada pelo seu pai José Antônio de Jesus na publicação do primeiro livro: Coroa de Lírios.

No prefácio da obra Cora Lírios, Felicio Duarte apresenta a trajetória poética de Leodegaria, afirmando que a poetisa apresenta um futuro promissor dentro da Literatura e que as criticas serão importantes para o seu crescimento intelectual. $O$ desenvolvimento intelectual em Leodegaria é percebido de imediato até pelos críticos que mesmo com poucos conhecimentos teóricos da poesia a mesma utiliza com simplicidade e beleza as palavras, houve aqueles como Gastão de Deus que apresentou severas criticas a poetisa, mas ao mesmo tempo acreditava que a jovem Leodegaria se tornaria uma poetisa no Estado de Goiás. FRANÇA (1996).

De acordo com FRANÇA (1996), em 1907, surgiu na cidade de Goiás o semanário chamado o Rosa, o primeiro circulo literário do estado de Goiás organizado por mulheres e que tinham como objetivo divulgar os acontecimentos literários e culturais em Goiás tendo como organizadoras: Cora-Coralina e Leodegaria de Jesus. $O$ nome do semanário era Rosa pois o jornal era impresso com tal cor.

Ainda neste período mesmo fazendo parte de um circulo literário, a jovem poetisa sofreu severas criticas entre elas: o uso exagerado das vírgulas e também um sentimentalismo muito acentuado na maioria dos poemas. (FRANÇA, 1996 p. 17 ). Assim como a criança ao lançar os primeiros passos precisa de quem lhe dê a mão e possa guia la com paciência e carinho e dessa forma, os principiantes mergulham na rigidez da critica para no futuro apresentarem uma arte da escrita com qualidade tal como ocorreu com Leodegaria (DENOFRIO, 2000)

Segundo FRANÇA (1996) a poetisa Leodegaria realiza a sua ultima produção poética com livro intitulado: Orquideas, a presente obra marcou a trajetória literária da jovem poetisa pelo fato da obra trazer a relação entre a poesia e o místico ou seja, a poetisa enfatiza o seu sofrimento amoroso e ao mesmo tempo lembra dos sofrimentos 
de Cristo e das dores na cruz. Assim, eu-Lirico de Leodegaria revela o aspecto religioso no poema Levando a Cruz por estas palavras:

Quando a Jesus cercado de Tortura,

De uma angustia cruel que não se exprime

A cruz levaram tão pesada e dura

Em que se devia consumar-se o crime. (DE JESUS, 1928. p.99).

Nestes versos: Quando a Jesus cercado de tortura/ De uma angustia cruel que não se exprime, o eu lírico relembra por meio da poesia o momento em que Cristo carregou a cruz até o calvário e expressa: A cruz levaram tão pesada e dura em que consume o crime. Esse conteúdo poético/religioso com o tema: sofrimento, faz entender que o formato poético do verso acima segue um quarteto bem acentuado entre as palavras: Tortura/ dura e exprime/ crime sempre nas rimas terminadas por vogais tal como fazia o poeta Luiz Camões como explica DENOFRIO, (2000).

A obra Orquidea portanto, é marcada por uma poética tanto de um real sofrimento bem como a busca de relacionar o sofrimento amoroso que viveu a poetisa ao sofrimento místico de Cristo tal como o eu lírico expressa no poema levando a cruz: De uma angustia cruel que não se exprime. (JESUS,1928, p. 99)

Ao relatar sobre o prefacio feito por Lellis Viera na obra Orquideas, TELES (1982) afirma que a poetisa não estava no número dos que se afundaram no modernismo tonto e anárquico, mas que pretende dar um novo olhar para a literatura, um olhar mais critico e inovador para a literatura goiana.

Felício Buarque no prefacio do livro Coroa de Lírios relata no prefacio a necessidade da poetisa se apresentar para o mundo poético goiano, ter coragem de enfrentar a critica e demonstrar o seu talento. Ainda explica que Leodegaria sendo uma principiante na poesia, tendo grande talento, precisa melhorar quanto à forma, mas não tanto o que exigir numa época em que os recursos literários em Goiás ainda não eram favoráveis.

Leodegaria de Jesus ao dar o passo inicial na poesia feminina em Goiás, publicando a sua primeira obra poética Coroa de Lírios, depara com as dificuldades como: a raridade feminina na cultura goiana, as duras criticas inicias que ela enfrentou o pouco desenvolvimento na literatura em Goiás. Mas a poetisa apesar das dificuldades deu abertura ao mundo poético feminino, quebrou uma tradição aonde o pensamento poético geralmente em Goiás, não poderia ser visto e pensador pelas mulheres. Ela, porém, abre para Goiás, os caminhos da poesia goiana numa dimensão cultural feminina.

A própria Poetisa Leodegaria de Jesus apresenta a obra Coroa de Lírios através do texto chamado: os patrícios. Neste prefacio, a poetisa manifesta a sua empolgação poética, referente à sua maravilhosa idade e seu coração inocente poético. Abaixo segue um trecho da introdução feito pela própria poetisa. 
Vi fugir de uma vez o bando azul das ledas phantasias que me acariciam desde a infância, imprimindo em minha alma o sello eterno da melancolia e não deixando de esperança, sinão uma mirrada plantinha, da qual brotaram alguns lírios pallidos, os quais colhi e formei esta singela coroa que examinaes agora.(DE JESUS, 1906, p.13)

Leodegaria de Jesus ao começar escrever seus versos poéticos de maneira simples, mas de forma profunda, buscou levar a sociedade goiana a mergulhar no mundo poético. Ela traz de um modo geral sentimentos de: Amor, Família, Saudades.

Tanto DENOFRIO (2001) e FRANÇA (1996) relatam que Leodegaria mesmo com as dificuldades familiares devido o falecimento do pai em 1920, a poetisa não desanimou quanto a produção e escrita das duas obras: Coroa de lírios e Orquideas. As dificuldades e as criticas vividas por parte da jovem poetisa não foram barreiras para que se tornasse uma grande poetisa em Goiás.

Devemos ceder uma curiosidade: Saber como a critica, dentro e fora de Goiás, se é que foi tão longe recebeu essa poetisa goiana.

Apesar da jovem poetisa ter um estilo poético considerado por críticos da época com traços de sentimentalismo romântico, é possível verificar em toda poética tanto de Coroa de Lírios e Orquideas um eu lírico demarcado por uma simetria formada por soneto tal como fazia o poeta do século XIV Luiz Camões ${ }^{4}$. Portanto, Leodegaria como explica FRANÇA (2000) encontra na poesia de Camões inspiração para compor seus versos. Todavia, os estudiosos: DENOFRIO(2001) E FRANÇA (1996) argumentam que a poetisa não teve formação teórica de poesia tal como já foi mencionado mas encontrou em alguns poetas como Castro Alves o seu estilo de poesia.

Referente à estrutura da poesia de Leodegaria de Jesus como apresenta Darcy França Denofrio. Dos 30 poemas de Coroa de Lírios, 18 são sonetos, dos 70 poemas de Orchideas, 52 são sonetos. A poetisa Leodegaria nas epígrafes demonstrava quais eram seus poetas prediletos: Álvares de Azevedo Garret Varelo e Castro Alves. Elementos temáticos são tratados dentro dos poemas Coroa de Lírios e Orchideas, como: Pátria, Família, Religião, amor impossível (DENÓFRIO, 2001)

\section{$\underline{\text { O devaneio poético e a poetisa Leodegária de Jesus }}$}

O devaneio é o repouso do ser, é a fuga para fora do real. Não é um vazio de espírito,é antes, o dom de uma hora que conhece a plenitude da alma. Neste sentido, aparece a anima (termo latim: alma) que vive o presente das imagens felizes. Nas horas de felicidade conhece um devaneio que se alimenta de si mesmo, que se mantém como a vida se mantém. BACHELARD, 1998. p. 61). Com isso no poema Mater, é

\footnotetext{
4

Muitos poemas que estão presente no livro Coroa de Lírios seguem o estilo do poeta Luiz Camões, um deles é o poema Triste Viver.
} 
possível encontrar alguns elementos referentes ao devaneio tais como: idealização, sonho, gozo, fuga do real/sofrimento.

\section{MATER}

Mãe é teu nome para mim um hymmo Maravilhoso, de celeste encanto.

Oh, como é doce, carinhoso e santo.

Pleno de graça, imenso, e até divino.

Minha mãe, minha mãe, só a teu lado,

Eu sinto-me feliz. O teu sorriso.

É para mim um sonho do paraíso.

O teu sorriso puro e imaculado.

Tu és meu anjo tutelar e amigo

És o thesouro que feliz bemdigo.

Formosa estrella que encontrei na vida

Quizera ver-te, num altar brilhante,

E eu de joelho, tua filha amante,

A venera-te, minha mãe querida (DE JESUS, 1906, p.17)

No poema Mater é visível o amor que Leodegaria coloca em sua mãe, e esse amor é sinal de felicidade para a poetisa, como é citado na segunda estrofe nos primeiros versos:

Minha mãe, minha mãe, só a teu lado,

Eu sinto-me feliz. O teu sorriso.(DE JESUS, 1906, p. 17)

BACHELARD (1998) ao relatar sobre o devaneio demonstra que o individuo deve buscar a felicidade e sair desse mundo real sofrido e materialista. $O$ devaneio poético não é um sonho noturno, mas um repouso para a alma, que leva boas lembranças da infância em plena luz da vida como fez a poetisa Leodegária de Jesus.

Tomando por base o método fenomenológico, Gaston Bachelard elaborou uma teoria que estabelece uma comunicação com a consciência criadora do poeta, lugar em que uma origem absoluta, uma gênese que faculta a consciência uma profunda percepção cósmica.

A Poetisa Leodegária de Jesus apresenta essa consciência cósmica quando eleva a sua mãe, personagem principal do seu poema Mater como desejo de valor sublime, o desejo de vê-la em um altar brilhante ao dizer: Tu és um anjo tutelar e amigo.

O poema Mater de Leodegaria, dedicado a sua mãe, como ela mesmo apresenta na introdução, apresenta algumas qualidades que a poetisa oferece: Anjo, Formosa Estrela, Nome Maravilhoso de celeste encanto. O poema inteiro é um enaltecer a pessoa da mãe, uma homenagem poética, um ato singelo. 
Os críticos ainda não viram com bons olhos esse aspecto sentimentalista presente em Leodegária devido a uma relação de Romantismo Arcaico e o Parnasianismo. Basileu França cita dois grandes críticos: O professor Francisco Ferreira e Gastão de Deus Vítor Rodrigues.

De acordo com BASILEU (1996), citando o professor Francisco Ferreira, a poetisa queria transmitir a ideia de amor perfeito e de uma possível fuga do sofrimento que a vida Ihe causou, transformando a desilusão amorosa em poesia. BASILEU (1996) citando também Gastão de Deus, afirmava que a poetisa trouxe na sua poética um eu lírico cheio de mágoas, tristeza e paixão, mas que ao mesmo tempo, por meio da poética o eu lírico encontra a felicidade e o amor ideal/platônico.

O filósofo Bachelard relatou sobre o devaneio poético, a imagem poética constitui um novo ser da linguagem, imagem poética, ilumina a consciência. Todavia, Otavio Paz revelou que poesia é sinal de salvação, capaz de transformar o mundo. A poesia revela esse mundo, revela o outro.

No poema Mater há uma revelação sobre a grandeza poética desse amor materno. "Tu és meu anjo tutelar. Anjo, figura celestial, é também símbolo de eternidade. Na Linguagem Bíblica a interpretação que se dá para anjo é referente a um mensageiro, aquele que acompanha, que guia, está perto.

Leodegaria ao colocar a palavra anjo para referir a sua mãe, está demonstrando que em toda a sua vida ela a compreendeu e a educou. A Poetisa viveu sempre ao lado dos seus pais, demonstrando um afeto muito forte, como se pode ver no poema Mater.(BASILEU, 1996)

PAZ(1982) explica que o poema de um modo geral, tem uma característica aonde ressoa a musica do mundo, a métrica e a rima entram em harmonia. Neste aspecto há o poema: "Símile" letra de Leodegaria de Jesus que mais tarde tornou melodia musical por Joaquim Santa Ana. Era muito escutada em serenatas goianas, abaixo segue o poema.

Símile ${ }^{5}$

Quando vivemos, a sonhar amores

Quando não temos a ilusão perdida

Quando nossa alma não padece dores

Morrer é triste. Como a vida é linda.

Mas si nos fere o espinho da tristeza.

Si maltratados somos pela sorte.

5

Este poema é a parte central de toda poética de Leodegaria, embora sendo um dos mais curtos traz uma dinamicidade de movimentos rítmicos que inspiram outros poemas tais como: Supremo Gozo e Suprema Dor. Símile foi musicalizado para ser cantado nas noites de serestas (FRANÇA, Basileu. Leodegaria de Jesus. Editora Kelps,1996) 
Si nos é dado o calix da incerteza.

Viver é triste. Como é doce a morte.(DE JESUS, 1906, p.19)

Neste poema símile, a poetisa apresenta uma relação entre o prazer de viver, colocando que a vida é linda e do outro lado devido aos espinhos da vida, a morte é mais doce.

Duas características são marcantes neste poema: Vida e Morte.

Em relação a expressão vida presente no poema símile. A poetisa faz uma dinâmica afirmando que a vida é sonho e não há sofrimento e nem dor e que portanto a vida é bela. Todavia, quando está presente a ideia da morte, há o espinho do sofrimento, da dor e da angustia e dessa forma há o cálice do sofrimento. Se a vida causa dor, a morte é doce e suave. Assim, há presente um traço da literatura romântica como: pessimismo, morte e angustia marcado poeticamente por uma antítese barroca: vida/ morte.

Sobre a palavra Morte há presente no poema: Fere o espinho da tristeza maltratados, somos pela sorte, o calix da incerteza, conclui-se como a morte é doce.

Tem se aí dois termos bem distintos que faz parte do mundo poético e real que Leodegária coloca de um lado a vida e morte. BACHELARD (1998) explicou que o devaneio poético, os sentidos se despertam e se harmonizam, estabelecendo os acordes da polifonia inédita que amplia na ressonância da imagem poética.

No poema símile, há uma figura de Linguagem denominada: antítese entre os termos: vida e morte/dor e gozo que formam uma dinâmica no decorrer da composição poética como se verifica no verso a seguir: Se nos é dado o cálice da incertezal como é triste viver/ Como é doce a morte. Nesta dinâmica entre viver é triste e doce é a morte, é possível compreender pro meio gramatical que as palavras vida e morte assumem ora função de substantivo e ora função de verbo, tal como se verifica na expressão do eu lírico: Morrer é triste! Como é linda a vida/Viver é triste como é doce a morte.

O eu lírico ao expressar que a morte é triste e a vida é linda, apresenta o seu estado de alegria e que ao mesmo tempo esse estado de gozo pode ser transformando em martírio como é expresso no verso: se nos é dado o cálice da incerteza/ como é doce a morte.

Leodegaria neste poema relata sobre a profundidade da angustia humana, referindo se angustia existencial, ao sofrimento, ao vazio, ao esquecimento e as dores, criando se uma perspectiva de felicidade que pode aparecer e amenizar a dor por meio do sonho.

Quando vivemos, a sonhar amores

Quando não temos a ilusão perdida (DE JESUS, 1906, p. 19)

BACHELARD (1998) refere-se ao sonho noturno e sobre o pensamento claro. O sonho noturno submete-se apo impulso que não obedecem a nossa vontade.Diferente,o devaneio ilustra o repouso do ser, pois o sonhador e seu devaneio entram de corpo e alma na felicidade. Portanto, o devaneio difere do sonho, trazendo a felicidade.

Aqui a poetisa apresenta um possível devaneio, ao utilizar na primeira estrofe a palavra quando os três versos. 
Quando vivemo, a sonhar amores

Quando não temos a ilusão perdida

Quando nossa alma não padece dores (DE JESUS, 1906, p. 19)

O eu lírico no verso acima ao expressar: Quando vivemos a sonhar amores/está querendo demonstrar que não há sofrimento e angústia mas, o gozo pleno da alma, pois nossa alma estando neste estado de plena ventura não pode padecer dores. Portanto, o eu lírico revela a possibilidade da alegria e do amor somente quando vivemos a sonhar amores.

De um modo geral, há vários poemas que revelam o sofrimento amoroso de Leodegaria presente no "Coroa de Lírios" Como explica DENOFRIO (2001). Citando os poemas: Suspiro e Ultimo Adeus. Seguindo um estilo de Álvares de Azevedo parece encontrar na morte a solução para o sofrimento amoroso, daí cita-se um trecho do próprio poema símile:

Si nos é dado o cálice da incerteza.

Viver é triste. Como é doce a morte.(DE JESUS, 1906, p.19).

Desse modo, o amor e a morte são inseparáveis no Romantismo. O amor é em principio, a fase afirmativa de um amor ideal, da vida, do anseio de viver extremamente, sentindo todos os prazeres e o gozo supremo da vida, êxtase que se realiza plenamente no prazer amoroso.(LIMA,2011, p.23)

Outro Poema que retrata do sofrimento amoroso como explica DENOFRIO (2001) é o poema Suspiro. Poema que apresenta traços de relações românticas: O doloroso pranto, as fases perdidas, o peito enfermo. Segue abaixo o poema Suspiro.

Suspiro

Quando tu passas, espalhando encanto

Meu triste olhar te segue apaixonado

O peregrino ser, por quem há tanto

Trago no seio um coração chagado

Então, eu fujo; um doloroso pranto

Cheio de Fel, de magoas repassadas

Inunda-me as fase pallidas, enquanto

Balbucio teu nome idolatrado

Si eu não te visse. oh Se me esquecesses

Talvez (quem sabe?) indo curar pudesses

Meu coração que tu despedaçaste

Mas, não, tarde, eu tenho o peito enfermo; 
E só a morte poderá pôr termo

Ao desgraçado amor que me inspiraste. (DE JESUS, 1906, p. 45-46).

Nos primeiros versos da primeira estrofe: Quando tu passas espalhando encanto/meu triste olhar te segue apaixonado, o eu lírico está diante de uma dialética entre: o olhar triste e ao mesmo tempo quando a pessoa amada passa espalhando encanto. Essa aproximação que o eu lírico traz em relação a pessoa amada, revela ao mesmo tempo um sentimento e olhar de tristeza. A dialética entre o olhar triste que o eu lírico revela e o encantamento vindo da pessoa amada, é possível compreender que o devaneio é a abertura do mundo belo, é a coerência do sonhador quando este é fiel aos seus sonhos. (BACHELARD, 1998. p. 17)

O verso: Se nos é dado o cálice da incerteza, viver é triste/como é doce a morte, permite compreender que o amor e o devaneio caminham juntos ora por meio do noturno (simbolizando: sonhos, paixão) e por outro lado por meio do termo diurno (simbolizando a criação e a idealização) e por isso, muitos amantes correm para escrever quando saem de seus encontros amorosos, pois o amor nunca termina de exprime-se tanto melhor quando mais praticamente é sonhado. (BACHELARD, 1998,p. 8).

O Amor e o devaneio poético caminham juntos, é por isso que muitos amantes correm para escrever assim quando saem dos seus encontros amorosos, pois, o amor nunca termina de exprimir-se tanto melhor quanto mais praticamente é sonhado. Os devaneios, de duas almas solitárias preparam a doçura do amor. Um realista da paixão virá aí apenas (BACHELARD, 1998, p. 8)

Assim, o eu lírico ao idealizar um amor feliz por meio da poética, se depara com o real/sofrimento e desse modo, o amor ideal fica apenas no plano poético e isso causa em Leodegaria sofrimento como explicam os estudiosos: FRANÇA(1996) e DENOFRIO(2001). A poetisa transforma a sua angústia amorosa em poesia quando expressa: Mas, não, tarde, eu tenho o peito enfermo/ e só a morte poderá por termo/ ao desgraçado amor que me inspiraste.

Segundo BASILEU (1996), não poder ser confirmado que Leodegaria teve um amor real, em contrapartida, DENOFRIO (2001) demonstra que o amor poético de Leodegaria é verdadeiro e que mesmo existiu revelado em segredo de estado por Rosarita Fleury que o único amor da poetisa Leodegaria se tratava de Djalma Guimarães. Amor rompido forçadamente quando ela tinha quinze anos.

FRANÇA (1996) relata que a poetisa Leodegaria mesmo não tendo na vida a concretização no amor tal como desejava, acabou por transformar esse sentimento amoroso em lindos versos poéticos como poder ser verificado no poema: Supremo Gozo. Neste poema, o eu lírico expressa: brandura, ventura, doçura, ternura e sempre rimando nos finais dos versos dando vida e dinâmica no poema tal como se verifica abaixo.

Supremo Goso 
Quando os teus olhos languidos, formosos,

Nos meus, se fitam, com ideal ternura,

Nesses olhares vagos, amorosos,

Vejo sorrir-me a vida, com douçura

Quando em teus lábios frescos e mimosos,

Paira um sorriso, cheio de brandura,

Então, minha alma, as regiões dos gosos,

Sinto evolar-se, plena de ventura.

Si te ouço a voz amena que deleita,

Mais que o cantar das aves peregrinas,

O alma santa, de minha alma eleita,

Muda-se logo o mundo em paraíso;

As alegrias puras e divinas,

A me affagarem, ternas, eu diviso.(DE JESUS, 1906, p. 49)

É um dos poucos poemas que trata sobre o amor de forma feliz, incluindo os poemas: Mutação e Estâncias. Os demais sete poemas que tratam do amor retratam como perde e sofrimento.

Abaixo mais um poema que trata da felicidade idealizada.

\section{Estâncias}

Quando me fitas esse olhar tão grave,

Tão doce e cheio de melancolia,

Fica minha alma em êxtase suave

Esqueço a vida, esqueço esta agonia

Que me tortura a alma, noite e dia

Quando me fitas esse olhar tão grave

Duma tristeza infinda de sol posto

São esses olhos lindos, sonhadores;

Nos quaes traduzo um perennal desgosto

Nos quaes diviso um barathro de dores.

Amo esses olhos cheios de dulçores,

Duma tristeza infinda de sol posto.

Oh, que me importam ríspidos martyrios,

Com que me cerca o fado traiçoeiro

$\mathrm{Si}$, nesses olhos tristes, como os círios,

Que valem mais do que o universo inteiro.

Encontro sempre um balsamo fagueiro?

Oh, que me importam ríspidos martyrios. (DE JESUS, 1906, p. 37). 
Nos versos: Quando me fitas esse olhar tão grave,/ tão doce e cheio de melancolial fica minha alma em êxtase suave, o eu lírico assim como no poema Supremo Gozo, revela a felicidade que sente quando a pessoa amada the parece próxima. Por isso afirma: Quando me fitas esse olhar tão grave e cheio de melancolia. Tal expressão feita pelo eu lírico é semelhante nestes versos: Quando em teus lábios frescos e mimosos/ pairava um sorriso cheio de brandura. Assim, tanto no poema Estâncias como em Supremo Gozo a aproximação que o eu lírico faz em relação a pessoa amada ocorre ao utilizar as seguintes expressões: Quando me fitas esse olhar tão grave/ tão doce e cheio de melancolia e quando em teus lábios frescos e mimosos/paira um sorriso, cheio de brandura.

$\mathrm{Na}$ época da Leodegaria de Jesus com o romantismo, era comum o tema amor ser tratado por muitos poetas goianos, com a poetisa não era diferente.

Quando me fitas esse olhar tão grave,

Tão doce e cheio de melancolia,

Fica minha alma em êxtase suave. (DE JESUS, 1906, p.37)

Aqui a poesia demonstra um olhar idealizado sobre a pessoa amada. $\mathrm{O}$ que importa é amar, não se preocupando com o sofrimento que pode acontecer, como é descrito no poema.

Encontro sempre um balsamo fagueiro?

Oh, que me importam ríspidos martyrios.(DE JESUS, 1906, p. 37)

$\mathrm{Na}$ segunda estrofe, a poetisa apresenta uma profundidade do olhar poético frente à pessoa amada.

Duma tristeza infinda de sol posto

São esses olhos lindos, sonhadores.(DE JESUS, 1906, p.37)

Como DENOFRIO (2001) Leodegaria apresenta dez poemas que tratam sobre o tema amor em Coroa de Lírios, e só três não tratam do sofrimento ao amor. São eles: Estância e Supremo Goso e Mutação.

\section{Comparação entre o poemas: Triste Viver e Soneto}

No poema Triste Viver, será analisado as principais semelhanças com um poema de Luiz Camões referente à estrutura, composição poética, rimas e conteúdo. No poema abaixo algumas palavras serão colocadas exatamente como era a ortografia no inicio do século XX no Brasil.O acordo ortográfico foi feito apenas em 1943.

Triste Viver

Não sei por que, da vida não alvorada,

Fugiu-me tão depressa a doce creança 
Lançando-me perto a indifferença

Deixando esta minha alma contristada.

De encontro às dores de tristeza imensa.

Da sorte cruelmente abandonada,

Sosinha, vae minha alma desvairada

Boiando a flor dos mares das creanças.

E sinto que meu peito desfallece, Ao peso dessas magoas que padece

As garras do pesar atroz profundo.

Contudo não maldigo a minha sorte, Pois, creio que virá um dia a morte

Tira-me, finalmente, deste mundo.( JESUS, 1906 ,p.59)

Agora um poema de Luiz Camões, feito por volta do século XIV.

Soneto

Tanto de meu coração me acho incerto,

Que em vivo ardor tremendo estou de frio;

Sem causa juntamente choro e rio,

O mundo todo abarca, e nada aperto,

E tudo sinto um desconcerto:

Da alma um fogo me sai, da vista um rio;

Agora espero, agora desconfio;

Agora desvario, agora acerto.

Estando em terra, chego ao céu voando;

Numa hora acho mil anos, e é de jeito

Que em mil anos não posso achar uma hora.

Se me pergunta alguém por que assim ando

Respondo que não sei; porém suspeito

Que só porque vos vi minha senhora ( CAMÕES, 2007, p.15).

A estrutura tanto no poema Triste Viver e no poema Soneto apresentam algumas semelhanças entre elas: ambos são estruturados em quarteto e terceto. As duas primeiras estrofes do poema Soneto são rimadas com a vogal o e no poema Triste Viver, Leodegaria articula o poema em rimas terminadas em a. Tal como será demonstrado abaixo na primeira estrofe de cada poema: Não sei por que, da vida não alvorada/ fugiu-me tão depressa a doce criança/ lançando-me perto a indiferente/Deixando esta minha alma contristada. (DE JESUS, 1906,p.5) e agora o 
primeiro verso do poema soneto: Tanto do meu coração me acho incerto/ que em vivo ardor tremendo estou de frio/ sem causa juntamente choro e rio/ o mundo todo abarca, e nada aperto (CAMÕES, p.15).

Neste sentido, o poeta encanta a linguagem por meio de ritmo. Uma linguagem suscita outra. Assim, a função predominante do ritmo distingue o poema de todas as outras formas literárias. O poema é um conjunto de frases, uma ordem verbal, fundada no ritmo (PAZ, Otavio, 1982, p. 68).

Nas duas primeiras estrofes do poema Soneto, as rimas terminam com mesma vogal, já na terceira estrofe, a rima intercala com o ultimo verso da estrofe anterior como se ver a seguir: Estando em terra, chego ao céu voando/Numa hora acho mil anos, e é de jeito/ Que em mil anos não posso achar uma hora.//Se me pergunta alguém por que assim ando/Respondo que não sei; porém suspiro/ Que só porque vos vi minha senhora. (CAMOES, p. 15).

A poetisa Leodegaria seguiu a mesma estrutura rítmica no poema Triste Viver, buscou uma unidade de rima entre a terceira e quarta estrofe. $E$ sinto que meu peito desfalece/ ao peso dessas magoas que padece/ as garras do pesar atroz profundo // Contudo, não maldigo a minha sorte/ pois creio que virá um dia a morte/ tirar-me finalmente deste mundo. (LEODEGARIA, 1906, p. 59). Assim, há uma harmônica poética tanto no poema Soneto e em Triste viver na terceira e quarta estrofe com as palavras: hora/ Senhora e mundo/profundo.

$\mathrm{Na}$ quarta estrofe tanto no poema Triste Viver e no poema de Luiz Camões, há uma possível solução para a dor e o sofrimento do eu lírico poético. Porém, Luiz Camões, apresenta em todo poema, um discurso dinâmico de ideias formando um conceito de antítese que percorre em toda construção poética $A$ poetisa Cecilia Meirelles, no poema chamado "motivo", demonstra claramente o aspecto da antítese. Abaixo, um trecho do poema:

Eu canto porque o instante existe, não sou alegre e não sou triste (MEIRELES, 2010, p. 10)

Camões no século XIV, já fazia essa dinâmica da antítese.

Agora espero, agora desconfio;

Agora desvario, agora acerto (CAMÕES, 2007)

Embora a poetisa Leodegaria siga a mesma estrutura poética de Camões, não há presente no poema Triste Viver uma noção de antítese, mas uma noção lógica dos fatos que vão acontecendo tendo como foco de ideia: o sofrimento sendo este uma das temáticas tratada pela poetisa. Todavia, há outro caminho que percorre a poesia de Leodegaria é a da idealização, do sonho e do romantismo que encanta a alma e faz que o eu lírico esqueça o real/sofrimento e construa o seu mundo real/poético. Com isso, o beneficio de uma poesia é que ela ensina a compreender a condição do homem como desejável; ela tem serenidade interior, um olhar feliz para o real e eleva o individuo ao universalmente humano. (FRIEDRICH, Hugo, 1978, p. 20).

\section{CONCLUSÃO}


A literatura Goiana de um modo geral tem o seu valor na arte poética quando permite que cada individuo descubra a arte do sensível e do devaneio. Ser poeta é ao mesmo tempo buscar um mundo melhor que não se limite ao campo das regras rítmicas mas que transcenda o tempo, as palavras. Pois o verdadeiro poeta é aquele que descobre a própria essência da linguagem transformando em Arte e esse é um caminho que exige esforços.

Leodagaria de Jesus abertura para o caminho da lírica em Goiás e ao escrever a primeira obra Coroa de Lírios seguindo o estilo poético Romântico tanto da primeira como da segunda fase, torna a presente obra neorromântica mas a poetisa não deixa a lírica ficar na monotonia dos versos mortos, mas sim, Leodegaria coloca dinâmica e vida em toda a poética de Coroa de Lírios: Quando nossa alma não padece dores/ morrer é triste/ Como é doce a morte. Por ser a primeira a ter um livro de poesia a ser publicado, Leodegaria abriu as portas para a poesia feminina em Goiás, um grande avanço para a Literatura Goiana. Portanto estudar a poetisa não é somente rever um passado da Literatura é com isso, apresentar a dinâmica poética no eu lírico feminino que trouxe para a poesia atual em Goiás.

Assim, demonstrando a importância da poética de Leodegaria para a literatura goiana, conclui-se que a poesia é uma revelação de uma realidade interior que atravessa abstratamente a realidade perceptível através dos sentidos, é materialização do desejo de um poeta sonhador a traduzir angustia de todos os poetas à procura do seu próprio ser no mundo (LIMA, 2012, p.9).

\section{REFERÊNCIAS}

ARISTÓTELES. A poética clássica. São Paulo: Editora Cultrix, 2005

BACHELARD, Gaston. A poética do Devaneio, 1998

CAMOES, Luiz. Sonetos Para amar o amor. Seleção de Sergio Faraco. Porto Alegre: L e PM Pocket, 2007.

DENOFRIO, França Darcy. Lavras de Dos Goiases III. Goiânia:Cânone Editora,2001.

FRANCA, Basileu. Leodegaria de Jesus. Editora Kelps, 1996

FRIEDRICH, Hugo. A estrutura da Lírica Moderna. Tradução Marise N. Curioni. São Paulo: Duas Cidades, 1978.

JESUS, Leodegaria de. Coroa de Lírios. Campinas. Editora Azul, 1906

LIMA, Maria de Fátima Gonçalves. leitura e poesia II. Coleção: verso e prosa, Kelps/editora PUC- GOIÁS, 2011.

Kelps/editora PUC- GOIÁS, 2012. . Leitura e poesia III. Coleção: verso e prosa, 
MEIRELES, CECILIA. A viagem. Editora Globo, 2010.

PAZ,Octavio. O arco e a liria. Trad. Olga Sarava. Rio de Janeiro: Nova Fronteira, 1982

TELES, Gilberto A Poesia em Goiás, Estudos Goianos I. Goiânia: UFG. Goiânia, 1982. 